\title{
Online Learning Strategy Of MTs Muhammadiyah 1 Taman During Pandemic Covid 19 [Strategi Pembelajaran Online MTs Muhammadiyah 1 Taman Di Masa Pandemi Covid-19]
}

\author{
Melinda Widyadana Dwi Pramesti* \\ \{melindawidya21@gmail.com\} \\ Fakultas Psikologi dan Ilmu Pendidikan, Universitas Muhammadiyah Sidoarjo, Indonesia
}

\begin{abstract}
The aim of this study is to find out online learning strategy of MTs Muhammadiyah 1 Taman in the middle of covid 19 pandemic. This research is descriptive qualitative research. Qualitative approach is a research process to understand about social problem by analyzing words and reporting detailed views of information that obtained from interviewees in a social environment.
\end{abstract}

Keywords: Online Learning, Pandemic Covid 19

\begin{abstract}
Abstrak. Tujuan penilitian ini untuk mengetahui strategi pembelajran online MTs Muhammadiyah 1 Taman di tengah covid 19. Penelitian ini merupakan penelitian kualitatif deskriptif. Pendekatan kualitatif merupakan proses penelitian untuk memahami masalahmasalah sosial dengan menganalisis kata-kata serta melaporkan pandangan informasi terperinci yang diperoleh dari para sumber informasi dalam lingkungan alami.
\end{abstract}

Kata Kunci: Pembelajaran Online, Pandemi Covid 19

\section{Pendahuluan}

Pendemi covid 19 memberikan banyak sekali dampak dari banyak pihak, kondisi seperti ini sudah merambah pada dunia pendidikan, pemerintah pusat yang banyak memberikan kebijkan unutk meliburkan seluruh lembaga pendidikan. Hal ini dilakukan sebagai upaya mencegah meluasnya penularan covid 19. Diharapakan dengan seluruh lembaga pendidikan tidak melaksanakan aktivitas seperti biasanya, hal ini dapat meminimalisir menyebarnya penyakit covid 19 ini. Oleh karena itu pembelajaran yang dialakukan pada masa pandemic ini dengan pemebelajaran online. Pembelajaran online adalah pembelajaran yang menggunakan jaringan internet dengan aksesibilitas, konektivitas, fleksibilitas, dan kemampuan untuk memunculkan berbagai jenis interaksi pembelajaran bahwa penggunaan internet dan teknologi multimedia yang mampu merombak cara penyampaian pengetahuan dan dapat menjadi alternatif pembelajaran yang dilaksanakan dalam kelas tradisional. Pembelajaran daring ini juga yang mampu mempertemukan siswa dan guru untuk melaksanakan interaksi pembelajaran dengan bantuan internet.[1]

Pembelajaran sendiri sangatlah penting bagi siswa karena siswa dapat menambah kemampuan dan potensi yang mereka miliki. Dalam kondisi pandemi saat ini menuntut pendidik untuk berinovasi menggubah pola pembelajaran tatap muka menjadi pola pembelajaran tanpa 
tatap muka. Zhafira, Ertika, dan Chairiyaton, menjelaskan bahwa terdapat model pembelajaran lain yang bisa digunakan oleh tenaga pengajar sebagai media penyampaian ilmu pengetahuan, yaitu pembelajaran daring dan pembelajaran campuran (kombinasi dari dua metode pembelajaran yaitu tatap muka dan pembelajaran daring). Metode pembelajaran daring tidak menuntut siswa untuk hadir di kelas. Siswa dapat mengakses pembelajaran melalui media internet.[2]

Di tengah pandemic covid 19 ini pembelajaran yang dilakukan MTs Muhammadiyah 1 Taman tidak menggunakan kurikulum khusus, melainkan tetap menggunakan kurikulum K13 dengan menambah durasi pembelajaran khususnya untuk pengumpulan tugas. Sedangkan fakta yang terjadi dalam pembelajaran online ini banyak sekali terjadi kendala pada saat proses pembelajaran sedang berlangsung seperti akses internet yang tidak stabil, dan fakta yang terjadi dari sekolah yang penulis teliti, banyak dari siswa yang kesulitan dalam akses internet, hand phone yang digunakan kurang mendukung dalam proses belajar dan lain sebagainya, tetapi dalam hal ini sekolah memberikan kemudahan dengan memberikan fasilitas kepada siswa untuk datang ke sekolah dengan menerapkan protokol kesehatan.

Berdasarkan dari penelitian ini dapat disimpulkan bahwasanya strategi pembelajaran sangat diperlukan dalam pembelajaran khususnya di tengah pandemic covid 19 untuk memudahkan siswa bisa memahami pembelajaran yang diberikan oleh pendidik. Dengan demikian dari proses pembelajaran daring ini diharapkan bisa dijadikan sebagai alternatif pendidik dalam menerapkan model-model pembelajaran yang bertujuan untuk menambah ilmu dan mengaplikasikan penggunaan kemajuan teknologi dengan baik dan benar.

\section{Metode Penelitia}

Artikel ini termasuk kedalam jenis penelitian pendekatan kualitatif. Pendekatan kualitatif ini diterapkan dalam penelitian ini untuk mendiskripsikan pelaksaan pembelajaran pada masa pandemic covid 19 di MTs Muhammadiyah 1 Taman. hal ini disebabkan karena dengan pendekatan kualitatif deskriptif dianggap lebih efektif digunakan dalam penelitian ini karena pendekatan ini dapat digunakan untuk menggali data secara mendalam. Subyek dalam penelitian ini adalah guru dan siswa di MTs Muhammadiyah 1 Taman.

Terdapat dua sumber data dalam penelitian ini yaitu sumber data primer dan sumber data sekunder. Sumber data primer dalam penelitian diperoleh secara langsung dari narasumber melalui wawancara dan observasi mengenai pelaksanaan pembelajaran pada masa pandemic covid 19. Sedangkan sumber data sekunder didapatkan melalui dokumentasi, catatan-catatan peniliti selama di lokasi. Selanjutnya dari data yang telah diperoleh melalui wawancara observasi, dan dokumentasi.

\section{Hasil dan Pembahasan}

\subsection{Strategi Pembelajaran MTs Muhammadiyah 1 Taman Sebelum Pandemi}

MTs muhammdiyah 1 Taman berlokasi di JL. Sambiroto, Gg Masjid Baitul Mugofar Kabupaten Sidoarjo. Awalnya madrasah ini bergabung dengan MI Muhammadiyah pada sekitar tahun 2008, Lalu MTs Muhammdiyah akhirnya berdiri sendiri dan melakukan renovasi pembangunan secara besar-besaran. Renovasi dilakukan mulai dari perbaikan ruang kelas, kantor guru, toilet dan membangun aula untuk mendukung pembelajaran. Tentunya bukan hanya sisi bangunan saja yang diubah melainkan kualitas mengajar dan sistem pembelajaran 
terus dikembangkan hingga sampai sekarang ini. Kelas yang ada di MTs Muhammadiyah 1 Taman dibedakan menjadi 2 yaitu kelas reguler dan kelas intensif. Kelas reguler di mana pembelajaran dilaksanakan dengan menggunakan Bahasa Indonesia seperti pada umumnya, sedangkan kelas intensif pembelajaran dilakukan dengan menggunakan Bahasa inggris atau bilingual dan akan ada ujian khusus untuk kelas intensif untuk mendapatkan sertifikat dari Cambridge Assessment International Education. Kegiatan yang ada di MTs Muhammadiyah juga sangat beragam yang bertujuan untuk memperdalam agama dan mengembangkan minat bakat siswa siswinya diantaranya adalah; One day boarding school, Kelas tahfidz (tahfidz reguler dan tahfidz intensif), BTQ (Baca tulis al-quran), One day qur'an, Diniyah, Al kahfi day, Literasi qur'an, Daurah tahfidzul qur'an 1 bulan minimal 3 juz, Ngaji morning, Tadarus keliling, Dhuha praying, Tadarus mandiri.

\subsection{Strategi dan proses Pembelajaran Mts Muhammadiyah 1 Taman di Tengah Pandemi}

Adanya covid 19 membuat kegiatan yang dilakukan menjadi sangat terbatas. Kegiatan belajar mengajar dilakukan secara daring melalui via zoom, google meet dan aplikasi e-learning khusus dari MTs Muhammadiyah 1 Taman untuk menunjang belajar dan mengajar. Beberapa kegiatan juga dilakukan secara daring dari rumah akan tetapi pembelajaran dilakukan melalui via zoom. Kegiatan tahfidz alqur'an dibimbing oleh guru tilawati dan diberlakukan absen untuk memastikan bahwa para siswa mengikuti kegiatan dengan baik. Absen dilakukan dari jam 16.00 - 17.00. Adapun one day boarding school, one day boarding school adalah kegiatan menginap di sekolah selama 1 hari, dengan diisi kegiatan-kegiatan bermanfaat seperti tahfidz qur'an, tadarus mandiri, sholat malam berjamaah dll. Dikarenakan kondisi yang tidak memungkinkan untuk melakukan kegiatan secara offline maka kegiatan dilakukan secara online melalui via zoom. Setiap anak akan di cek oleh wali kelas dan guru pembimbing, kegiatan sholat malam juga dilakukan secara daring yakni melakukan sholat malam melalui via zoom dengan diawasi oleh guru pembimbing.[3]

Guru akan memberikan pegawasan terhadap seluruh siswa dalam pembelajaran online, jika ada murid yang tidak mengikuti kegiatan pembelajaran, maka guru akan menindak lanjuti anak tersebut. Guru juga memberikan laporan kepada wali murid bagaimana perkembangan dan kendala yang dialami oleh murid dalam kegiatan pembelajaran sehingga orang tua dapat mengetahui dan memonitoring sang anak dengan baik. Laporan dilakukan setiap 2 minggu sekali dalam bentuk nilai sehingga wali murid dapat mengetahui perkembangan belajar anakanaknya. Guru mengantisipasi apabila ada murid yang terkendala sarana dan prasarana maupun jaringan yang kurang memadai maka sekolah akan memfasilitasi anak tersebut untuk datang ke sekolah dan guru akan menjelaskan secara langsung, sehingga anak dapat langsung menerima pelajaran dari guru. Tentu saja dengan menggunakan protokol kesehatan mulai dari memkai masker, membawa hand sanitizer, mencuci tangan dll sehingga siswa yang datang ke sekolah tetap menaati protokol kesehatan.[4]

\subsection{Problematika Yang Dihadapi Mts Muhammdiyah 1 Taman di Tengah Pandemi}

Terdapat berbagai macam problematika yang dihadapi MTs Muhammadiyah 1 Taman di tengah pandemi ini salah satunya adalah psikis murid yang ada di MTs Muhammadiyah 1 Taman. Pembelajaran daring yang dilakukan membuat keadaan siswa dan siswi MTs Muhammdaiyah 1 Taman kurang semangat dalam mengikuti pembelajaran. Hal ini berbeda saat pembelajaran tatap muka di mana para siswa dan siswi giat dalam belajar. Tentu saat 
pembelajaran tatap muka para siswa dapat belajar secara langsung dengan guru dan temantemannya, sehingga mereka dapat menjalankan kegiatan dengan baik dan pembelajaran menjadi efektif, tetapi saat pembelajaran online mereka tidak dapat bertemu secara langsung dengan guru maupun teman-temannya sehingga mereka jadi sedikit stress dan pembelajaran menjadi kurang efektif.[5]

Hal ini diperburuk dengan kendala jaringan dan teknologi yang tidak memungkinkan berdampak pada kurangnya semangat siswa dalam melakukan pembelajaran. Adapun anak yang kurang disiplin dalam menaati peraturan juga merupakan efek dari pembelajaran daring yang membuat anak menjadi stress dan tidak semangat dalam menjalani pembelajaran.[6]

\subsection{Dampak Pandemi Covid 19 Terhadap Kegiatan Yang Ada di Mts Muhammadiyah 1 Taman}

Covid 19 yang terjadi memiliki banyak sekali dampak salah satunya terhadap kegiatan belajar mengajar. Terdapat 2 dampak yang ditimbulkan yaitu dampak positif dan dampak negatif. Dampak positifnya adalah pengumpulan tugas menjadi lebih fleksibel, para murid dapat mengerjakan tugas kapan saja dan dapat melakukan kegiatan lain. Contoh, pelajaran yang diberi dapat dikumpulkan maksimal jam 12.00 WIB sehingga para murid dapat mengerjakannya kapan saja tetapi tidak diperkenankan melebihi jam yang telah ditentukan. Dampak negatifnya dalah guru menjadi bekerja dua kali lebih ekstra dalam pembelajaran karena guru harus menyiapkan dan menjalelaskan materi secara online dan guru juga harus mengawasi para murid agar tidak absen dalam pembelajaran. Hal ini juga berdampak dengan jam kerja para guru yang menjadi lebih lama.[7]

Tanggung jawab yang dipikul menjadi lebih berat karena guru juga harus memonitoring para murid dengan ekstra. Akan ada saknsi yang diberikan pada murid yang tidak mengerjakan atau terlambat dalam pengumpulan tugas, hal ini menyebabkan para guru harus bekerja lebih lama lagi dikarenakan murid yang tidak melaksanakan kegiatan yang telah ditentukan. Selain itu dampak negatif dari pembelajaran online di MTs Muhammadiyah adalah administrasi menjadi lebih sulit dan biaya untuk sarana dan prasarana menjadi lebih banyak. Dapat disimpulakan bahwa dampak positif pembelajaran ini lebih untuk para murid dengan keleluasaan dalam megerjakan dan mengumpulkan tugas sementara dampak negatifnya lebih untuk para guru dan pihak sekolah di mana para guru harus kerja lebih ekstra dan biaya yang dikeluarkan menjadi lebih banyak.[8].

\section{Kesimpulan}

Demikianlah karya ilmiah strategi tentang pembelajaran MTs Muhammadiyah I Taman di tengah pandmi covid 19. Pembelajaran yang awalnya dilaksanakan secara langsung kini dilaksanakan secara online melalui platform digital seperti zoom, google meet dll. Pembelajaran bersifat online yang dilaksanakan tentulah memiliki sisi positif dan negatif. Maka dari itu para siswa dan guru diharapkan untuk dapat bekerja sama dalam menyelenggarakan pembelajaran secara online ini. Dengan demikian pembelajaran tetap dapat berjalan dengan baik walaupun di tengah situasi pandemi covid 19. Pendidikan merupakan hal yang sangat penting maka dari itu bagiamanapun situasinya pendidikan harus tetap terlaksana dengan baik. Hal ini menjadi tugas penting untuk pemerintah dan juga para guru. Dengan menerapkan normal baru ini merupakan langkah awal dalam menghadapi pandemi covid 19 ini. 


\section{Ucapan Terima Kasih}

Tidak lupa penulis mengucapkan terimakasih untuk kepala sekolah MTs Muhammadiyah 1 Taman beserta bapak dan ibu guru yang bersedia membantu penulis dalam menyelesaikan tulisan ini. Penulis juga tidak lupa mengucapkan terima kasih pada rekan-rekan seperjuangan yang telah membantu penulis sehingga penulis dapat menyelesaikan artikel ini dengan baik.

\section{References}

[1] A. P. Putri, R. S. Rahhayu, M. Suswandari, and P. A. R. Ningsih, "Strategi Pembelajaran Melalui Daring Dan Luring Selama Pandemi Covid-19 Di Sd Negeri Sugihan 03 Bendosari," Prima Magistra J. Ilm. Kependidikan, vol. 2, no. 1, pp. 1-8, 2021, doi: 10.37478/jpm.v2i1.728.

[2] A. Septiani and M. T. B. Kejora, "EDUKATIF : JURNAL ILMU PENDIDIKAN Tingkat Aktivitas Belajar Siswa pada Pembelajaran Online Pendidikan Agama Islam di Masa," vol. 3, no. 5, pp. 2594-2606, 2021.

[3] A. Solihin, "Pembelajaran Online dengan Aplikasi Zoom Meeting," vol. 3, no. 2, pp. 17-23, 2020.

[4] N. Mardiana and E. Widayat, "Strategi Pembelajaran di Masa Pandemi , Pada Kelompok Bermain 'Flamboyan' Cokrok usuman, Yogyakarta," vol. 4, no. 2, pp. 208-220, 2021.

[5] S. A. Harahap, D. Dimyati, and E. Purwanta, "Problematika Pembelajaran Daring dan Luring Anak Usia Dini bagi Guru dan Orang tua di Masa Pandemi Covid 19," J. Obs. J. Pendidik. Anak Usia Dini, vol. 5, no. 2, pp. 1825-1836, 2021, doi: 10.31004/obsesi.v5i2.1013.

[6] K. D. Yuangga and D. Sunarsi, "Vol. 4 No. 3 Juni 2020," ( Kharisma dan Denok, 2020 ), vol. 4, no. 3, pp. 51-58, 2020.

[7] F. Firmansyah, "Motivasi Belajar dan Respon Siswa terhadap Online Learning sebagai Strategi Pembelajaran di Masa Pandemi Covid-19," Edukatif J. Ilmu Pendidik., vol. 3, no. 2, pp. 589-597, 2021, doi: 10.31004/edukatif.v3i2.355.

[8] I. R. V. Oishi, "Pentingnya Belajar Mandiri bagi Peserta Didik di Perguruan Tinggi," IKRA-ITH Hum., vol. 4, no. 2, pp. 50-55, 2020, [Online]. Available: https://journals.upi-yai.ac.id/index.php/ikraith-humaniora/article/download/555/407/. 